\title{
Laboratory-Based Safety Assessment Tests of Some Nigerian Commercial Herbal Products
}

\author{
Raymond I Ozolua* and Dickson O Uwaya \\ Department of Pharmacology and Toxicology, Faculty of Pharmacy, University of Benin, Benin City 300001, Nigeria
}

\begin{abstract}
Introduction: Herbal medicines are becoming increasingly popular for many reasons one of which is the belief in their safety. Nonetheless, prior to their listing/registration, safety evaluation is a requirement by national regulatory agencies and the World Health Organization.

Materials and Methods: Four commercial polyherbal products were screened for acute and sub-acute toxicity Acute toxicity tests involved determination of $\mathrm{LD}_{50}$ and observing rats and mice for gross toxicological symptoms Groups of rats were administered $2 \mathrm{~g} / \mathrm{kg} /$ day of the polyherbal products for 28 days at the end of which some hematological and biochemical indices were evaluated.

Results: The dose of $8 \mathrm{~g} / \mathrm{kg}$ of each herbal product did not cause death in the animals suggesting much higher $\mathrm{LD}_{50}$ values. The hematological and biochemical indices were largely normal except for decrease in serum sodium or potassium in two of the products.

Conclusions: These polyherbal products appear safe in rats and mice but further studies are required to assess safety in humans. The procedures in this study may be adopted as a mandatory first step in the safety screening of herbal products.
\end{abstract}

Keywords: Safety; Herbal medicines; Acute tests; Sub-acute tests

\section{Introduction}

The majority of people who live in developing countries rely on alternative methods for their healthcare [1]. Herbal medicine is a major component of alternative medicine. The proliferation of herbal medicines in Nigeria may be attributed to the influence of technology which has placed adverts on herbal products near the people. Secondly, the high cost of orthodox medicine has led to refocusing on herbal products. The availability of many well-packaged products from the United States and China seems to have challenged herbalists in Nigeria. Rather than prepare these herbal medicines on extemporaneous basis, many are now involved in large scale commercial production often with good packaging. They also strive to adhere to the guidelines of the national regulatory agency (National Agency for Food and Drug Administration and Control). Toxicological assessment of herbal medicines is also a requirement by the World Health Organization [2].

It was in this regard of evaluating safety that samples of $\mathrm{Kool}^{\circledR}$, Yaami $^{\circledR}$, Nosawit ${ }^{\circledR}$ and Paaba ${ }^{\circledR}$ (all polyherbal medicinal products) were given to us. Rodent-based toxicity tests usually provide information on the safety of medicinal products and chemicals meant for human use [3]. We here describe our protocol which could be adopted as a first step in assessing the safety of herbal medicines.

\section{Materials and Methods}

\section{Plant materials}

The manufacturing company (Helt Waiz Herbal Products Nigeria Ltd) was requested to bring large quantities of the pulverized plant materials containing the same proportion of the constituents stated in the label of each product. The information on labels and presentation of each polyherbal product are shown in Table 1 . Quantities $(2 \mathrm{~kg})$ of each powdered product were macerated in $4 \mathrm{~L}$ of distilled water for $48 \mathrm{~h}$ with occasional stirring. They were thereafter filtered two times each through a clean white cloth. The extracts were concentrated in a rotary evaporator and later dried in an oven set at $40^{\circ} \mathrm{C}$ for $24 \mathrm{~h}$. The extracts were packed into amber-colored bottles and stored in a fridge until they were used for tests.

\section{Animals}

Adult Sprague-Dawley rats $(200-250 \mathrm{~g})$ and albino mice $(20-$ $25 \mathrm{~g}$ ) of both sexes were used for the experiments. The animals were obtained from the Animal House, Ambrose Alli University, Ekpoma. They were housed in standard plastic cages with free access to rat pellets (Bendel Feeds and Flour Mill, Ltd, Ewu) and water. They were exposed to natural lighting and room temperature. All animals were handled according to international protocols for use of animals for experiments (National Institute of Health USA: Public Health Service Policy on Humane Care and Use of Laboratory Animals, 2002). The experiments were approved by institutional ethical committee.

\section{Acute toxicity tests}

These were carried out for each of the extract using standard methods [3-5]. Rats $(n=48)$ were randomly assigned to 6 groups of 8 (4 males and 4 females) per group. Group 1 rats were given $5 \mathrm{ml} / \mathrm{kg}$ of distilled water which was the vehicle for reconstituting the extracts. Rats in groups 2-6 were given 1, 2, 4, 6, and $8 \mathrm{~g} / \mathrm{kg}$ body weight of an extract respectively using an orogastric tube. The test was also carried out in mice using the same grouping and animal number per group. After

*Corresponding author: Raymond I. Ozolua, Dept of Pharmacology and Toxicology, Faculty of Pharmacy, University of Benin, Benin City 300001, Nigeria, Phone: +2348023528166; E-mail: ozolua@uniben.edu

Received May 15, 2013; Accepted August 22, 2013; Published September 2, 2013

Citation: Ozolua RI, Uwaya DO (2013) Laboratory-Based Safety Assessment Tests of Some Nigerian Commercial Herbal Products. J Pharmacovigilance S1: 001. doi:10.4172/2329-6887.S1-001

Copyright: @ 2013 Ozolua RI, et al., This is an open-access article distributed under the terms of the Creative Commons Attribution License, which permits unrestricted use, distribution, and reproduction in any medium, provided the original author and source are credited. 


\begin{tabular}{|c|c|c|c|c|}
\hline & Herbal Constituents & Dosage Form & Indication(s) & Dosage Regimen \\
\hline $\mathrm{Kool}^{(\mathbb{R}}$ & $\begin{array}{l}\text { Allium cepa Extract ( } 50 \mathrm{mg}) \text { Allium } \\
\text { ascatonicum }(75 \mathrm{mg}) \text { Viscum album } \\
(125 \mathrm{mg})\end{array}$ & $\begin{array}{l}\text { Hard gelatin capsules containing } \\
\text { powered plant materials }\end{array}$ & $\begin{array}{l}\text { Reduction of symptoms associ- } \\
\text { ated with high blood pressure }\end{array}$ & $\begin{array}{l}2 \text { to } 3 \text { capsules to be taken } 2 \text { times } \\
\text { daily }\end{array}$ \\
\hline Yaami $^{\circledR}$ & $\begin{array}{l}\text { Musa paradisiaca - }(200 \mathrm{mg}) \text { Aframo- } \\
\text { mum melegueta }(50 \mathrm{mg})\end{array}$ & $\begin{array}{l}\text { Hard gelatin capsules containing } \\
\text { plant materials }\end{array}$ & $\begin{array}{l}\text { Quick ejaculation, watery sperm } \\
\text { and purification of sperm }\end{array}$ & 2 capsules to be taken 2 times daily \\
\hline Noswit ${ }^{\circledR}$ & $\begin{array}{l}\text { Curcuma domestica }(62.5 \mathrm{mg} / 500 \mathrm{ml}) \\
\text { Picralima nitida }(62.5 \mathrm{mg} / 500 \mathrm{ml}) \\
\text { Cassia alata }(125 \mathrm{mg} / 500 \mathrm{ml})\end{array}$ & Green-coloured liquid & $\begin{array}{l}\text { Reduction of the symptoms as- } \\
\text { sociated with diabetes }\end{array}$ & $\begin{array}{l}4 \text { spoonfuls to be taken } 2 \text { times daily } \\
\text { (adult); } 2 \text { spoonfuls to be taken } 2 \text { times } \\
\text { daily (children above } 13 \text { years) }\end{array}$ \\
\hline Paaba $^{\circledR}$ & $\begin{array}{l}\text { Erythrophleum invorense } \\
(150 \mathrm{ml}) \text { Khaya senegalensis }(150 \mathrm{ml}) \\
\text { Carica papaya }(75 \mathrm{ml}) \text { Psidium guajava } \\
(125 \mathrm{ml})\end{array}$ & Orange-coloured liquid & Antimalarial dietary supplement & $\begin{array}{l}4 \text { spoonfuls to be taken } 2 \text { times daily } \\
\text { (Adults); } 3 \text { spoonfuls to be taken } 2 \\
\text { times daily (children above } 10 \text { years); } \\
1 \text { spoonful to be taken } 2 \text { times daily } \\
\text { (children below } 10 \text { years) }\end{array}$ \\
\hline
\end{tabular}

Table 1: Labels and presentations of the polyherbal products.

administration of each extract, all animals were observed for deaths within $72 \mathrm{~h}$ in first instance and then for 14 days. Gross toxicological features such as writhing, piloerection, ptosis, diarrhea, depression, convulsion and hypermotility were monitored

\section{Sub-acute toxicity tests}

Standard methods were used [6-9]. Forty rats were randomly allotted into 5 groups of 8 rats ( 4 males and 4 females) each. Group 1 animals were administered $5 \mathrm{ml} / \mathrm{kg}$ of distilled water per day for 28 days. Groups $2-5$ were administered $2 \mathrm{~g} / \mathrm{kg} /$ day body weight $(\times 28$ days $)$ of the extracts of $\mathrm{Kool}^{\mathbb{B}}$, Yaami ${ }^{\mathbb{B}}$, Noswit ${ }^{\mathbb{B}}$ and Paaba ${ }^{\circledR}$ respectively. The animals were fasted overnight prior to their use on the $29^{\text {th }}$ day. Extract administration was by the oral route in all cases.

Each animal was anaesthetized by chloroform inhalation and blood was obtained from the abdominal aorta. Each blood sample was divided into two portions: one into sodium EDTA bottle for hematological analysis and the other portion into lithium heparin bottle for biochemical assays.

Serum was obtained by allowing blood in specimen bottles to clot and retract. The serum samples were centrifuged at $3000 \mathrm{rpm}$ and then separated by use of Pasteur pipettes into clean bottles. The serum samples were stored at $-20^{\circ} \mathrm{C}$ until analyzed by using Chemwell Chemistry autoanalyzer (Awareness Technology, USA, model 2910). Aspartate aminotransferase (AST) and alanine aminotransferase (ALT) were assayed by the method described by Schumann et al. [10]. Serum creatinine was quantified by kinetic method of Larsen [11]. While total serum protein was assayed by the Biuret method [12], serum albumin was quantified by the method of Doumas et al. [13].

White Blood Cell (WBC), Platelet Count (PC), Packed Cell Volume (PCV), Hemoglobin Concentration (HB), and the WBC cell differentials (lymphocytes (LYM) and neutrophils (NEU)) were all analyzed by use of an automated blood analyzer (QBC Autoread Plus, UK). The blood samples were first pipetted into QBC capillary tubes and spun in a parafuge centrifuge (Becton Dickson, UK) for 5 min and read by means of an autoread analyzer $[8,9]$.

Hearts and kidneys of the bled animals were obtained and kept for $10 \mathrm{~min}$ in filtered paper before they were weighed $[8,9]$.

\section{Statistics}

The results are presented as mean \pm SEM (standard error of mean) and $\mathrm{n}$ represents the number of animals used. Data from control and each extract-treated group were compared by use of the Student's $t$-test (GraphPad Prism software, USA). $p<0.05$ indicates statistically significant difference between compared data.

\section{Results}

All the rats survived acute doses (of each extract) as high as $8 \mathrm{~g} / \mathrm{kg}$ for the 14 days of observation. Therefore the median lethal dose $\left(\mathrm{LD}_{50}\right)$ was indeterminate. The rats did not exhibit any gross toxicological sign except writhing and reduced locomotion which were observed in the groups given doses $\geq 4 \mathrm{~g} / \mathrm{kg}$ (Table 2 ).

Only one mouse died (4 days after) in the group given $8 \mathrm{~g} / \mathrm{kg}$ extract of Noswit ${ }^{\mathbb{B}}$. As in the rats, writhing and reduced locomotion were observed in the surviving mice which received the highest doses of 6 or $8 \mathrm{~g} / \mathrm{kg}$ (Table 3 ).

Table 4 shows the weight analysis of rats after 28 days of daily treatment with $2 \mathrm{~g} / \mathrm{kg}$ of the extract of each herbal product. All rats gained weight with the weight gain statistically significant $(p<0.05)$ in the group which received extract of Paaba ${ }^{\circledR}$. Organ-to-body weight ratios were not significantly affected by the treatments.

Table 5 shows that hematological parameters were not significantly altered by daily administration of $2 \mathrm{~g} / \mathrm{kg}$ of the extracts. Values of white blood cell count, hemoglobin concentration, packed cell volume and platelet counts were not altered by any of the extracts.

The biochemical parameters are shown in Table 6. Plasma sodium levels were significantly $(p<0.05)$ reduced in the Yaami ${ }^{\circledR}$-treated group while potassium levels were significantly $(p<0.05)$ reduced in the Paaba-treated group ${ }^{\mathbb{R}}$. In all other cases these plasma electrolytes were not significantly altered. Compared with control, the levels of plasma aspartate aminotransferase (AST) and alanine aminotransferase (ALT) were not significantly altered by treatment with extracts of $\mathrm{Kool}^{\circledR}$, Yaami ${ }^{\circledR}$ and Paaba ${ }^{\circledR}$. However, the levels of these two enzymes

\begin{tabular}{|c|c|c|c|}
\hline Dose (g/kg) & $\begin{array}{c}\text { Number of Deaths/ } \\
\text { Number of Rats }\end{array}$ & \% Mortality & Symptoms \\
\hline 0 & $0 / 8$ & 0 & None \\
\hline 1 & $0 / 8$ & 0 & None \\
\hline 2 & $0 / 8$ & 0 & None \\
\hline 4 & $0 / 8$ & 0 & None \\
\hline 6 & $0 / 8$ & 0 & $\begin{array}{c}\text { Writhing, reduced } \\
\text { locomotion which lasted } \\
\text { about 2 hours after } \\
\text { extract administration } \\
\text { Writhing, reduced } \\
\text { locomotion which lasted } \\
\text { about 2 hours after } \\
\text { extract administration }\end{array}$ \\
\hline 8 & $0 / 8$ & 0 & \\
\hline
\end{tabular}

Table 2: Result of acute toxicological test on each aqueous extract of the polyherbal products in rats. Animals were observed for $72 \mathrm{~h}$ in the first instance and then for 14 days after drug administration. The table represents all four products. 


\begin{tabular}{|c|c|c|c|}
\hline Dose (g/kg) & $\begin{array}{c}\text { Number of Deaths/ } \\
\text { Number of Mice }\end{array}$ & $\begin{array}{c}\% \text { Mortal- } \\
\text { ity }\end{array}$ & Symptoms \\
\hline 0 & $0 / 8$ & 0 & None \\
\hline 1 & $0 / 8$ & 0 & None \\
\hline 2 & $0 / 8$ & 0 & None \\
\hline 4 & $0 / 8$ & 0 & $\begin{array}{c}\text { Writhing, reduced locomotion } \\
\text { which lasted about 2 hours after } \\
\text { extract administration }\end{array}$ \\
\hline 6 & $0 / 8$ & 0 & $\begin{array}{c}\text { Writhing, reduced locomotion } \\
\text { which lasted about 2 hours after } \\
\text { extract administration }\end{array}$ \\
\hline 8 & $11^{*} / 8$ & 12.5 & \\
\hline
\end{tabular}

${ }^{*}$ Died on the 4th day in the Noswit ${ }^{\circledR}$ group.

Table 3: Result of acute toxicological test on each aqueous extract of the polyherbal products in mice. Animals were first observed for $72 \mathrm{~h}$ and then for 14 days after drug administration. The table represents all four products.

\begin{tabular}{|c|c|c|c|}
\hline & $\begin{array}{c}\text { Weight Change } \\
(\mathbf{\%})\end{array}$ & K:BW $\left(\times \mathbf{1 0}^{-4}\right)$ & H:BW $\left(\times \mathbf{1 0} \mathbf{0}^{-4}\right)$ \\
\hline Control & $6.07 \pm 2.92$ & $3.35 \pm 0.11$ & $3.22 \pm 0.10$ \\
\hline Kool $^{\circledR}$ & $11.89 \pm 5.21$ & $3.10 \pm 0.09$ & $3.23 \pm 0.09$ \\
\hline Yaami $^{\circledR}$ & $13.63 \pm 4.12$ & $3.06 \pm 0.14$ & $2.98 \pm 0.10$ \\
\hline Noswit $^{\circledR}$ & $13.14 \pm 2.59$ & $2.88 \pm 0.17$ & $3.05 \pm 0.12$ \\
\hline Paaba $^{\circledR}$ & $14.53 \pm 2.71^{*}$ & $2.75 \pm 0.05$ & $2.93 \pm 0.08$ \\
\hline
\end{tabular}

${ }^{*} \mathrm{P}<0.05$ compared to control. $\mathrm{H}: \mathrm{BW}$, heart-to-body weight ratios; $\mathrm{K}: \mathrm{BW}$, kidney-tobody weight ratios. $n=8$ per group

Table 4: Body and organ weight indices following oral treatment with $2 \mathrm{~g} / \mathrm{kg}$ body weight/day $(\times 28)$ aqueous extract of each of the polyherbal product.

\section{\begin{tabular}{l|l|l|l|l|l|}
$\begin{array}{l}\text { WBC } \\
(\times 1000 / \mu L)\end{array}$ & LYM (\%) & NEU (\%) & PCV (\%) & HB (g/dL) & $\begin{array}{l}\text { PC } \\
(\times 1000 / \mu L)\end{array}$
\end{tabular}}

\begin{tabular}{l|l|l|l|l|l|l|}
\hline Control & $13.5 \pm 1.3$ & $60.6 \pm 3.2$ & $25.8 \pm 3.1$ & $34.5 \pm 1.8$ & $12.1 \pm 0.4$ & $648.4 \pm 67.9$
\end{tabular}

\begin{tabular}{|l|l|l|l|l|l|l|l|}
\hline Kool $^{\otimes}$ & $13.3 \pm 2.3$ & $60.8 \pm 3.2$ & $24.7 \pm 1.9$ & $31.7 \pm 1.1$ & $11.2 \pm 0.5$ & $673.8 \pm 84.8$ \\
\hline
\end{tabular}

\begin{tabular}{|l|l|l|l|l|l|l|} 
Yaami $^{\circledR}$ & $14.8 \pm 2.6$ & $66.5 \pm 3.2$ & $25.8 \pm 2.7$ & $36.2 \pm 0.8$ & $11.9 \pm 0.7$ & $578.2 \pm 102.7$
\end{tabular}

\begin{tabular}{l|l|l|l|l|l|l|} 
Noswit $^{\circledR}$ & $13.2 \pm 1.1$ & $60.4 \pm 7.9$ & $31.5 \pm 5.1$ & $35.4 \pm 0.9$ & $11.4 \pm 0.5$ & $692.3 \pm 96.2$
\end{tabular}

\begin{tabular}{|l|l|l|l|l|l|l|} 
Paabal $^{\circledR}$ & $12.3 \pm 0.96$ & $58.3 \pm 10.4$ & $26.7 \pm 4.3$ & $34.3 \pm 0.7$ & $12.7 \pm 0.9$ & $558.7 \pm 74.3$
\end{tabular}

Table 5: Hematological indices following oral treatment with $2 \mathrm{~g} / \mathrm{kg}$ body weight/ day $(\times 28)$ aqueous extracts of the polyherbal products. Values are not significantly different. WBC, white blood cell count; LYM, lymphocytes; NEU, neutrophils

$\mathrm{PCV}$, packed cell volume; HB, hemoglobin; $\mathrm{PC}$, platelet count. $n=5-7$ per group.

\begin{tabular}{|c|c|c|c|c|c|c|}
\hline & $\begin{array}{l}\text { PROT } \\
\text { g/dl) }\end{array}$ & $\begin{array}{l}\text { ALB (mg/ } \\
\text { dl) }\end{array}$ & L & $A$ & & $\begin{array}{l}\text { POTAS- } \\
\text { SIUM } \\
(\mathrm{mM} / \mathrm{L})\end{array}$ \\
\hline & & & & & & \\
\hline (1) & \pm 0.1 & 4 & 42. & 136 & & \\
\hline Yaam & & & & & & \\
\hline Noswit $^{\circledR}$ & \pm 0.2 & 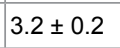 & $1.0 \pm 3.4^{*}$ & $74.2 \pm 16.2^{* *}$ & .7 & $5.2 \pm 0.3$ \\
\hline aaba ${ }^{\circledR}$ & $5.1 \pm 0.3$ & $3.6 \pm 0.2$ & $43.7 \pm 6.3$ & $141.4 \pm 11.6$ & $141.3 \pm 1.4$ & $4.9 \pm 0.2$ \\
\hline
\end{tabular}

${ }^{*} p<0.05$ compared to control; ${ }^{* *} p<0.002$ compared to control. T. PROT, total protein; ALB, albumin; ALT, alanine aminotransferase; and ASP, aspartate aminotransferase. $n=5-7$ per group

Table 6: Effects of 28 days daily oral treatment with $2 \mathrm{~g} / \mathrm{kg}$ body weight aqueous extracts of the polyherbal products on some biochemical parameters

were significantly (ALT, $p<0.05$; AST, $p<0.002)$ reduced by extract of Noswit ${ }^{\mathbb{B}}$. Plasma albumin was significantly increased by extract of $\mathrm{Kool}^{\mathbb{R}}$ compared with the control but there were no statistically significant differences in the levels of total proteins.

\section{Discussion}

The doses used in these safety assessment tests are far in excess of what is recommended for medicinal indications for each of the polyherbal products (Table 1). For example the labeled dose of $\mathrm{Kool}^{\circledR}$ is 2 to 3 capsules ( 500 to $750 \mathrm{mg}$ ) of the mixture of powdered plant materials to be taken two times a day. This is rather low compared to the acute dose of $8 \mathrm{~g} / \mathrm{kg}$ of the pure extract tolerated by the animals. Products with $\mathrm{LD}_{50}$ values $\geq 5 \mathrm{~g} / \mathrm{kg}$ are generally accepted to be safe $[4,14]$. Similarly, the daily dose of $2 \mathrm{~g} / \mathrm{kg}$ over a period of 28 days is very high but it is used in the absence of $\mathrm{LD}_{50}$ values [5,7]. If the animals were able to tolerate these high doses, much lower doses could even be better tolerated. None of the animals presented with blood related and biochemically-related toxic effects after 28 days of treatment thereby suggesting that they might be safe. The animals gained weight over the period. Elevation in plasma AST and ALT is usually diagnostic of damage to internal organs particularly the liver $[14,15]$. This was not observed. Rather one of them $\left(\right.$ Noswit $\left.^{\mathbb{R}}\right)$ lowered the levels of these enzymes. Significant reduction in plasma sodium or potassium could have clinical implications. Considering the dosage regimen used in the test and the indications for the herbal products involved, the reductions may not be of serious toxicological consequence.

In conclusion the acute and sub-acute toxicity tests carried out on the polyherbal products $\mathrm{Kool}^{\circledR}$, $\mathrm{Yaami}^{\circledR}$, Noswit ${ }^{\circledR}$ and Paaba ${ }^{\circledR}$ show that they appear safe in rats and mice but further studies are required to assess safety in human. The tests in this study are simple and are a step towards the entrenchment of pharmacovigilance of herbal products in developing countries.

\section{Acknowledgment}

The assistance and expert opinions of Dr SE Idogun (Consultant, Department of Chemical Pathology) and Dr CE Omoti (Consultant, Department of Hematology and Blood Transfusion) of the University of Benin Teaching Hospital are appreciated. Helt Waiz Herbal Products Nig. Ltd sponsored the study and gave consent for the publication of the results.

\section{References}

1. Osujih M (1993) Exploration of the frontiers of tradomedical practices: basis for development of alternative medical healthcare services in developing countries. J R Soc Health 113: 190-194.

2. World Health Organization (1996) Expert Committee on Specifications for Pharmaceutical Preparations. Thirty-fourth report. Technical Report Series No. 863: 178-184.

3. Echobichon DJ (1997) The basis of toxicological testing. CRC Press, New York, USA.

4. OECD (2001a) Organization of Economic Co-operation Development Guidelines for toxicity testing of chemicals. Test no. 420: Acute oral toxicityFixed Dose Procedure, OEDC, Paris, France.

5. Miller LC, Tainter ML (1944) Estimation of the LD50 and its error by means of logarithmic probit graph paper. Proc Soc Exp Biol Med 57: 261-264.

6. OECD (2001b) Organization of Economic Co-operation Development Guidelines for testing of chemicals. 407, Repeated Dose 28-Day Oral Toxicity Study in Rodents, OECD, Paris, France.

7. Bautista AR, Moreira EL, Batista MS, Miranda MS, Gomes IC (2004) Subacute toxicity assessment of annatto in rat. Food Chem Toxicol 42: 625-629.

8. Ozolua RI, Anaka ON, Okpo SO, Idogun SE (2009) Acute and sub-acute toxicological assessment of the aqueous seed extract of Persea americana mill (Lauraceae) in rats. Afr J Tradit Complement Altern Med 6: 573-578.

9. Ozolua RI, Idogun SE and Tafamel GE (2010). Acute and sub-acute toxicological assessment of aqueous leaf extract of Bryophyllum Pinnatum (Lam.) in Sprague-Dawley rats. Am J Pharmacol. Toxicol 5: 145-151.

10. Schumann G, Bonora R, Ceriotti F, Férard G, Ferrero CA, et al. (2002) IFCC primary reference procedures for the measurement of catalytic activity concentrations of enzymes at 37 degrees $\mathrm{C}$. International Federation of Clinical Chemistry and Laboratory Medicine. Part 5. Reference procedure for the measurement of catalytic concentration of aspartate aminotransferase. Clin Chem Lab Med 40: 725-733.

11. Larsen K (1972) Creatinine assay by a reaction-kinetic principle. Clin Chim Acta 41: 209-217. 
Citation: Ozolua RI, Uwaya DO (2013) Laboratory-Based Safety Assessment Tests of Some Nigerian Commercial Herbal Products. J Pharmacovigilance S1: 001. doi:10.4172/2329-6887.S1-001

Page 4 of 4

12. Doumas BT, Bayse DD, Carter RJ, Peters T Jr, Schaffer R (1981) A candidate reference method for determination of total protein in serum. I. Development and validation. Clin Chem 27: 1642-1650.

13. Doumas BT, Watson WA, Biggs HG (1971) Albumin standards and the measurement of serum albumin with bromcresol green. Clin Chim Acta 31: 87-96.
14. Karthikeyan S, Gobianand K, Pradeep K, Mohan CV, Balasubramanian MP (2006) Biochemical changes in serum, lung, heart and spleen tissues of mice exposed to sub-acute toxic inhalation of mosquito repellent mat vapour. $J$ Environ Biol 27: 355-358.

15. Wittekind C (1995) Prognostic factors in liver tumors. Verh Dtsch Ges Pathol 79: $109-115$

This article was originally published in a special issue, Toxicology of Natural Products handled by Editor(s). Dr. Maria Laura Colombo, Associate Professor, Department of Science and Drug Technology University of Turin, Italy 